\title{
Oesophageal adenocarcinoma is associated with a deregulation in the MYC/MAX/MAD network
}

\author{
JKR Boult', P Tanière', MT Hallissey ${ }^{2}$, MJ Campbell ${ }^{3}$ and C Tselepis*,I \\ 'CRUK Institute for Cancer Studies, University of Birmingham, Vincent Drive, Birmingham B 5 2TH, UK; ${ }^{2}$ University Hospital Birmingham NHS \\ Foundation Trust, Birmingham B 15 2TH, UK; ${ }^{3}$ Department of Pharmacology and Therapeutics, Roswell Park Cancer Institute, Buffalo, NY I 4263, USA
}

\begin{abstract}
Oesophageal adenocarcinoma, which arises from an acquired columnar lesion, Barrett's metaplasia, is rising in incidence more rapidly than any other cancer in the Western world. Elevated expression of c-MYC has been demonstrated in oesophageal adenocarcinoma; however, the expression of other members of the MYC/MAX/MAD network has not been addressed. The aims of this work were to characterise the expression of c-MYC, MAX and the MAD family in adenocarcinoma development and assess the effects of overexpression on cellular behaviour. mRNA expression in samples of Barrett's metaplasia and oesophageal adenocarcinoma were examined by qRT-PCR. Semi-quantitative immunohistochemistry and western blotting were used to examine cellular localisation and protein levels. Cellular proliferation and mRNA expression were determined in SEGI cells overexpressing c-MYCER or MADI using a bromodeoxyuridine assay and qRT-PCR, respectively. Consistent with previous work expression of c-MYC was deregulated in oesophageal adenocarcinoma. Paradoxically, increased expression of putative c-MYC antagonists MADI and MXII was observed in tumour specimens. Overexpression of c-MYC and MAD proteins in SEGI cells resulted in differential expression of MYC/MAX/ MAD network members and reciprocal changes in proliferation. In conclusion, the expression patterns of c-MYC, MAX and the MAD family were shown to be deregulated in the oesophageal cancer model.
\end{abstract}

British Journal of Cancer (2008) 98, 1985-1992. doi:I0.1038/sj.bjc.6604398 www.bjcancer.com

Published online 20 May 2008

(c) 2008 Cancer Research UK

Keywords: c-MYC; MAD; oesophageal adenocarcinoma; Barrett's metaplasia

The incidence of oesophageal adenocarcinoma has increased more rapidly over the past three decades than any other cancer in the Western world and continues to rise (Bollschweiler et al, 2001; Lagergren, 2005). The prognosis for patients with oesophageal adenocarcinoma remains extremely poor with median survival time merely 18 months post-diagnosis and 5-year survival rates approximating just $10 \%$ in most European populations (Sant et al, 2003). Barrett's metaplasia, characterised by the replacement of the native stratified squamous epithelium of the distal oesophagus with a heterogeneous columnar mucosa, is the most prominent risk factor for oesophageal adenocarcinoma (Jankowski et al, 2000; Lagergren, 2005). The estimated annual risk of progression to adenocarcinoma in individuals with Barrett's metaplasia is $0.2-1 \%$, which equates to $30-125$ times the risk in the general population (Hage et al, 2004; Solaymani-Dodaran et al, 2004).

c-MYC is an oncogenic transcription factor, which, as part of a heterodimeric complex with MAX, activates the expression of a diverse range of genes implicated in cellular processes such as cell growth, proliferation, loss of differentiation and apoptosis (Nesbit et al, 1999; Grandori et al, 2000). Deregulated or elevated expression of c-MYC has been documented in a wide range of human malignancies and is often associated with tumours of an aggressive, poorly differentiated phenotype (Dang, 1999; Nesbit et al, 1999). The role of c-MYC in tumorigenesis is complex; its

*Correspondence: Dr C Tselepis; E-mail: c.tselepis@bham.ac.uk Received 28 January 2008; revised 14 April 2008; accepted 15 April 2008; published online 20 May 2008 activation is mediated by a wide range of direct and indirect mechanisms (Salghetti et al, 1999; Bernasconi et al, 2000; Chiariello et al, 2001) and its precise role in cell proliferation, growth arrest and apoptosis is dependent on tissue type and environment (Pelengaris et al, 2000). In addition, myc overexpressing mice demonstrate increased incidence of tumours (Pelengaris et al, 1999). The expression of c-MYC in human oesophageal malignancy has previously been documented, demonstrating that c-MYC expression is elevated in Barrett's metaplasia and further overexpressed in oesophageal adenocarcinoma (Tselepis et al, 2003; Schmidt et al, 2007). The gene encoding c-MYC is located within chromosomal region $8 \mathrm{q} 23-24.2$, a region frequently amplified in adenocarcinomas of the oesophagus and gastro-oesophageal junction and that has been detected in Barrett's metaplasia (Walch et al, 2000; Croft et al, 2002; Doak et al, 2003; van Dekken et al, 2006).

The MAD family of transcriptional repressors, including MAD1 and MXI1, also bind to MAX and are believed to antagonise the activity of MYC proteins by competing for MAX-binding and interaction with E-box sequences in target gene promoters, and by actively repressing transcription of MYC target genes (Ayer et al, 1993; Zervos et al, 1993; Hurlin et al, 1995b). Their roles in terminal differentiation and growth arrest, and their ability to block MYC-induced transformation have led to them being postulated as tumour suppressor genes (Ayer et al, 1993; Zervos et al, 1993; Cultraro et al, 1997; Queva et al, 1998). However, to date little evidence to confirm this has been published and there is conflicting evidence as to whether putative MYC antagonist MXI1 
is lost or mutated in human cancers (Gray et al, 1995; Bartsch et al, 1996; Kuczyk et al, 1998).

There have been a number of isoforms of MXI1 isolated from glioblastoma and haematological cells that suggest dominant negative activity; antagonising the normal activity of MXI1 and demonstrating differential expression (Engstrom et al, 2004, Kawamata et al, 2005). Of particular interest is MXI1-0, an isoform with an alternative first exon, which demonstrates elevated expression in glioblastoma, aberrant cellular localisation and fails to repress c-MYC dependent transcription (Engstrom et al, 2004).

While c-MYC expression has been widely characterised in oesophageal adenocarcinoma, expression of members of the MAD family of putative c-MYC antagonists is yet to be studied in any detail in gastrointestinal carcinogenesis. The gene-encoding MAD1 (MXD1) has previously been identified as one of six genes downregulated at the transcriptional level in oesophageal adenocarcinoma (Hourihan et al, 2003), however, this observation has not been confirmed and other members of the MAD family have not been addressed. We hypothesised that MAD expression would be repressed in the progression of oesophageal adenocarcinoma in a reciprocal pattern to c-MYC. Overexpression of MAD family proteins in other cell systems has demonstrated decreased cell cycling and reduced apoptosis, therefore, we postulate that modulating the expression of MAD1 would have a similar effect in SEG1 cells and may represent a mechanism by which tumour growth could be retarded.

\section{MATERIALS AND METHODS}

\section{Ethics}

This work has been carried out in accordance with the Declaration of Helsinki (2000) of the World Medical Association. Ethical approval for this study was approved by University Hospital Birmingham Trust (LREC 2003/331). All patients provided informed written consent.

\section{Patient tissue}

(i) Oesophageal adenocarcinoma resection specimens. Samples of oesophageal adenocarcinoma $(n=37)$, some of which were matched with Barrett's metaplasia (BM) from the same resection specimen $(n=11)$, were collected during surgery and each tissue specimen was divided for RNA and protein extraction and pathological confirmation.

(ii) Endoscopic specimens. Samples of long segment $(\geqslant 3 \mathrm{~cm})$ Barrett's metaplasia $(n=14)$, defined as columnar mucosa with intestinal type goblet cells, with matched normal oesophageal squamous mucosa $(\mathrm{S})$ and gastric fundal mucosa $(\mathrm{F})$ from the same patient were collected during routine endoscopy. Any patients with Barrett's metaplasia with evidence of dysplasia or adenocarcinoma were excluded from this study.

(iii) Archived tissue. Paraffin sections of normal oesophagus $(n=10)$, normal gastric fundus $(n=10)$, Barrett's metaplasia $(n=25)$, Barrett's with dysplasia (BD, $n=20)$ and oesophageal adenocarcinoma (OAC, $n=25$ ) were identified within an archived tissue bank, Department of Pathology, Queen Elizabeth Hospital Birmingham, and processed for immunohistochemistry.

\section{Quantitative real-time RT-PCR}

Quantitative real-time RT-PCR ( $\mathrm{qRT}-\mathrm{PCR}$ ) was performed as described previously (Brookes et al, 2006) using $18 \mathrm{~S}$ ribosomal RNA as an internal standard (Applied Biosystems, Warrington, $\mathrm{UK})$ and sets of primers and 5'FAM 3'TAMRA probes listed in Table 1.
Table I Taqman probe and primer sequences used for $\mathrm{QRT}-\mathrm{PCR}$

\begin{tabular}{ll}
\hline Gene & Sequence \\
\hline MYC & \\
Forward & TCAAGAGGTGCCACGTCTCC \\
Reverse & TCTTGGAGCAGGATAGTCCTT \\
Probe & CAGCACAACTACGCAGCGCCTCC \\
MXDI & \\
Forward & CCTTAAAACGGAGGAACAAATCC \\
Reverse & AGCGAAGATGAGCCCGTCTA \\
Probe & AAAAGATAACAGCAGTAGCAGATCAACTCACAATGAAA \\
& \\
MXII (Exon I/2 boundary) \\
Forward & GGGAGCGAGAGTGTGAACATG \\
Reverse & TTCTGTGCCGGCTCAAC \\
Probe & CCCGACTGCAGCATTCAAAGCCC \\
MXII-0 (Exon O/2 boundary) \\
Forward & CTACCTGGAGCAGATCGAGAAAG \\
Reverse & TCGGCATGGACGGGAT \\
Probe & AAACAAAAATGTGAACATGGCTACGCCTC \\
MAX & \\
Forward & AGGTGGAGAGCGACGAAGAG \\
Reverse & GTGCATATGATGAGCCCGTII \\
Probe & CCGAGGTTCAATCTGCGGCTGAC \\
\hline
\end{tabular}

\section{Western blotting}

Western blotting was performed as described previously (Brookes et al, 2006) with a mouse monoclonal antibody to c-MYC $\left(1 \mu \mathrm{g} \mathrm{ml}^{-1}\right.$, clone 9E10, Applied Biosystems) or a rabbit polyclonal antibody to MAD1 $\left(1 \mu \mathrm{g} \mathrm{ml}^{-1}\right.$, clone C-19, Autogen Bioclear, Calne, Wiltshire, UK) or MXI1 $\left(1 \mu \mathrm{g} \mathrm{ml}^{-1}\right.$, clone G-16, Autogen Bioclear). A mouse monoclonal antibody to cytokeratin 19 (CK19) $\left(0.5 \mu \mathrm{g} \mathrm{ml}^{-1}\right.$, cloneA53-B/A2.26; Merck Chemicals Ltd, Nottingham, UK) was employed for normalisation of epithelial protein loading. Immunoreactive bands were subject to densitometry using a BioRad GS800 calibrated densitometer and Quantity one software. Where available a blocking peptide was used to confirm specific immunoreactive bands (MAD1 $5 \mu \mathrm{g} \mathrm{ml}^{-1}$; MXI1 $5 \mu \mathrm{g} \mathrm{ml}^{-1}$ ).

\section{Immunohistochemistry}

Immunohistochemistry was performed as previously described (Brookes et al, 2006) using microwave antigen retrieval and antibodies to c-MYC $\left(2 \mu \mathrm{g} \mathrm{ml}^{-1}\right)$, MAD1 $\left(2 \mu \mathrm{g} \mathrm{ml}^{-1}\right.$, clone FL-221, Autogen Bioclear), MXI1 $\left(2.7 \mu \mathrm{g} \mathrm{ml}^{-1}\right)$ or MAX (50 $\mathrm{ng} \mathrm{ml}^{-1}$, clone C-17, Autogen Bioclear). Positive control tissue was included, and omission of primary antibody and, where available, blocking peptides (MXI1 $13.5 \mu \mathrm{g} \mathrm{ml}^{-1}$; MAX $250 \mathrm{ng} \mathrm{ml}^{-1}$ ) were used as negative controls. The slides were scored by a previously described method for (i) intensity of staining $(0=$ negative, $1=$ weak, $2=$ moderate, $3=$ intense) and (ii) percentage of epithelial cells staining $\quad(0=0-5 \% ; \quad 1=6-25 \% ; \quad 2=26-50 \% ; \quad 3=51-75 \%$; $4=76-100 \%)$. These two values were multiplied to yield a final staining score of between 0 and 12. In addition, cellular localisation was assessed (Di Martino et al, 2006). All sections were scored independently by two observers.

\section{Cell culture}

The cell line SEG1 (Hughes et al, 1997; a kind gift of Dr David Beer, University of Michigan, Ann Arbour, MI) was routinely cultured in DMEM with $10 \%$ FCS supplemented with $100 \mathrm{U} \mathrm{ml}^{-1}$ penicillin and $0.1 \mathrm{mg} \mathrm{ml}^{-1}$ streptomycin (Invitrogen, Paisley, Renfrewshire, UK). 
Cells were transfected with pcDNA3.1-MYCER, encoding a chimeric protein that consists of human c-MYC fused at its carboxyl terminus to the hormone-binding domain of a mutant mouse oestrogen receptor (Littlewood et al, 1995), pcDNA3-MAD1 or the corresponding empty vector using Lipofectamine and Plus reagent according to manufacturer's instructions (Invitrogen). Twenty-four hours after transfection with c-MYCER, the fusion protein was activated by replacing the medium with $100 \mathrm{nM}$ 4-hydroxytamoxifen (4-OHT) (or control medium). Cells were cultured for a further $24 \mathrm{~h}$ before cells processing for RNA or protein or up to $96 \mathrm{~h}$ for a proliferation assay.

\section{Bromodeoxyuridine incorporation assay}

A colorimetric cell proliferation ELISA was performed according to the manufacturer's instructions (Roche Applied Biosystems, Burgess Hill, Sussex, UK). Briefly, cells were labelled with bromodeoxyuridine (BrdU) followed by fixation and incubation with anti-BrdU peroxidase, the immune complex was then detected using a 3,3,5,5-tetramethylbenzidine substrate reaction with the reaction product assessed at $370 \mathrm{~nm}$.

\section{Statistics}

All data are presented as means \pm 1 s.e.m. Statistical significance was calculated using paired $t$-test for mRNA analysis, MannWhitney test for analysis of immunohistochemical staining and unpaired Student's $t$-test for in vitro data. Significance was accepted at $P \leqslant 0.05$. All analyses were performed using SPSS version 10.0 (SPSS Inc., Chicago, Illinois, USA).

\section{RESULTS}

mRNA expression of the MYC/MAX/MAD network in Barrett's metaplasia and oesophageal adenocarcinoma

Quantitative real-time RT-PCR was utilised to assess the expression of the mRNAs encoding c-MYC, MAD1, MXI1, MXI1-0 and MAX in normal epithelia, Barrett's metaplasia and oesophageal adenocarcinoma specimens. This revealed that all the transcripts analysed were expressed at a higher level in oesophageal adenocarcinoma tissue than in matched normal gastric (Figure 1) and oesophageal (data not shown) controls. The only gene to be significantly altered in Barrett's metaplasia in comparison with normal gastric mucosa was MXI1-0, the alternatively transcribed isoform of MXI1. When expression in adenocarcinoma was evaluated in comparison to matched Barrett's metaplasia it was apparent that expression of MYC, MXI1 and $M A X$ were significantly elevated in the malignant transformation of Barrett's metaplasia.

Expression of MYC and MAD family proteins in Barrett's metaplasia and oesophageal adenocarcinoma

Western blotting analysis was employed to confirm the alteration in expression at the protein level. In comparison to matched normal gastric controls the expression of c-MYC and MXI1 was significantly upregulated in Barrett's metaplasia; conversely, the expression of MAD1 was significantly lower in the metaplastic lesion than in the normal mucosa (Figure 2). In accordance with the mRNA data c-MYC, MAD1 and MXI1 expression was significantly higher in oesophageal adenocarcinoma than in matched normal gastric controls. While a difference in $M Y C$ and MXI1 was demonstrated between Barrett's metaplasia and adenocarcinoma at the level of mRNA, there was no significant alteration in protein expression in malignancy. However, while MXD1 expression was not altered at the transcript level, MAD1
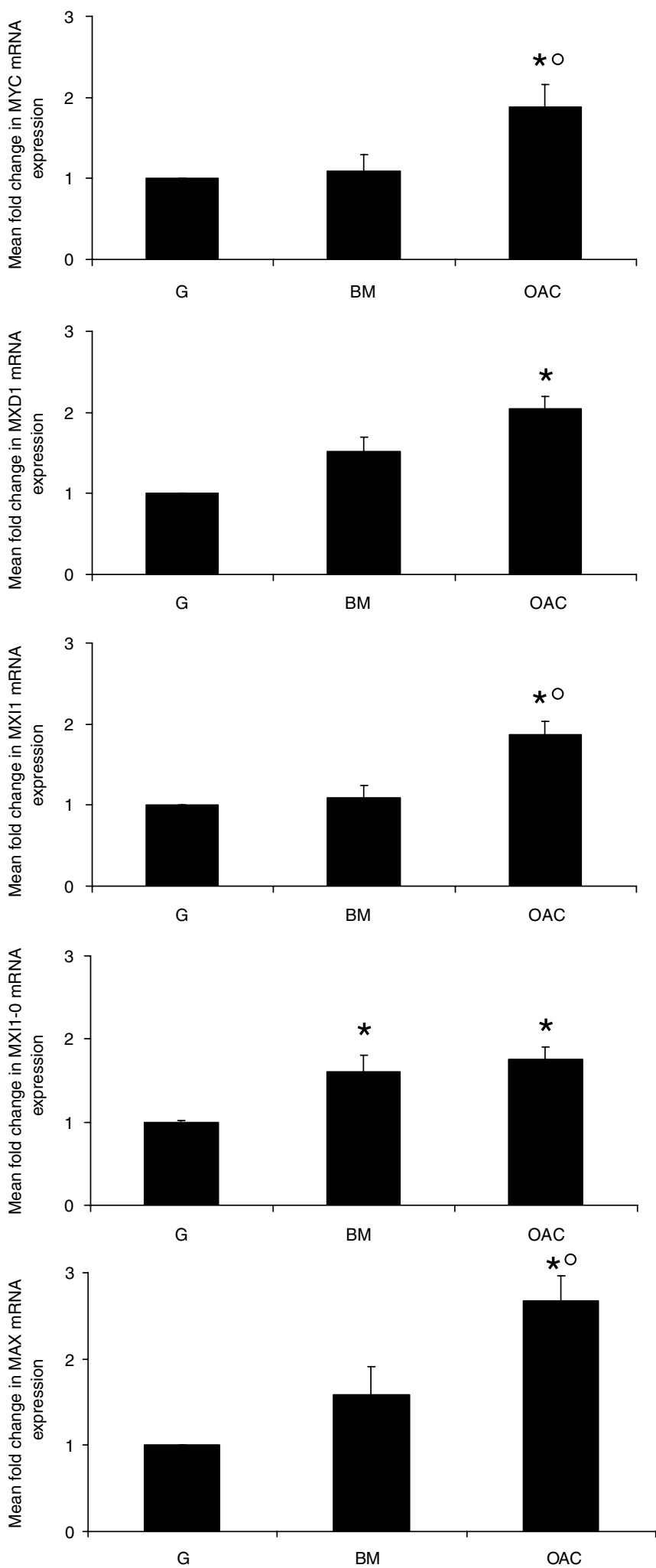

Figure I mRNA expression of MYC/MAX/MAD network genes in Barrett's metaplasia and oesophageal adenocarcinoma. GRT-PCR was used to examine expression of genes encoding c-MYC, MADI, MXII, MXII-O and MAX in Barrett's metaplasia (BM $n=25)$ and oesophageal adenocarcinoma (OAC $n=37$ ). Graphs represent mean fold change relative to matched normal gastric control ( $G$, normalised to one) \pm I s.e.m. * denotes significant change relative to $G,{ }^{\circ}$ denotes significant difference between $\mathrm{BM}$ and $\mathrm{OAC}(P<0.05)$. 

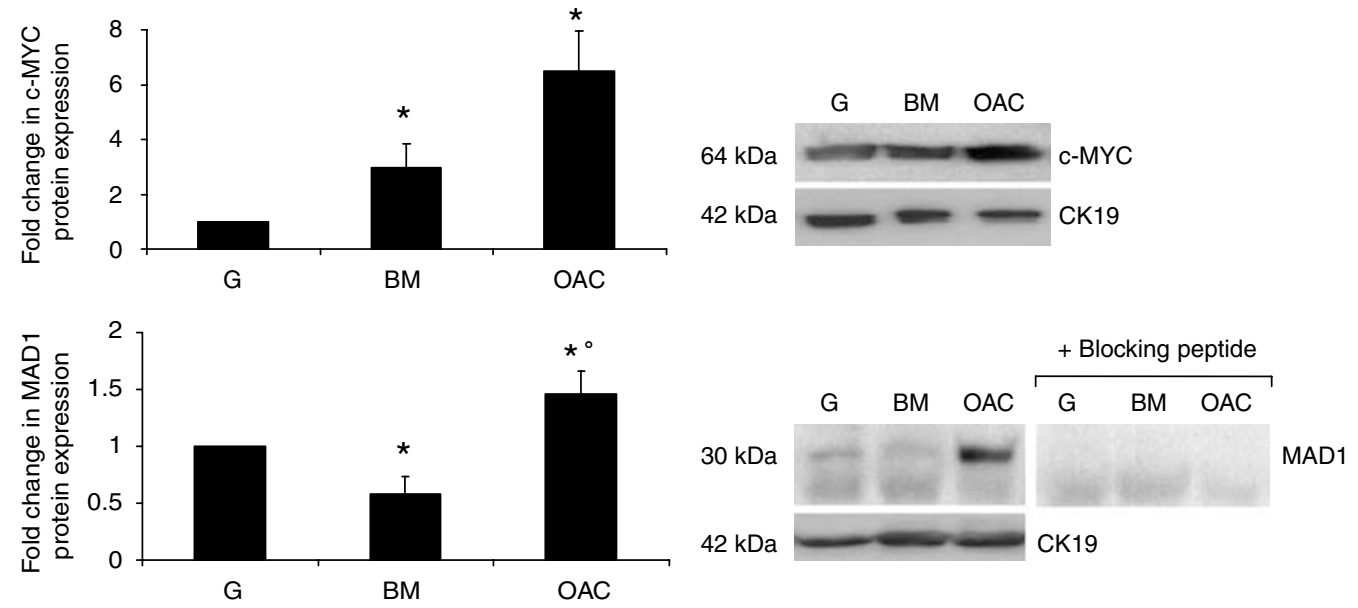

protein was expressed more highly in adenocarcinoma than Barrett's metaplasia.

\section{Immunolocalisation of MYC/MAX/MAD network proteins in the progression to oesophageal adenocarcinoma}

Immunohistochemical staining was utilised to establish $\mathrm{MYC} /$ MAX/MAD network protein localisation in normal oesophageal and gastric epithelia, Barrett's metaplasia, dysplastic Barrett's epithelium and oesophageal adenocarcinoma (Figure 3). To allow semi-quantitative evaluation of protein expression, the epithelial component of each section was scored as described in the methods for intensity of immunoreactivity and percentage of epithelial cells stained (Di Martino et al, 2006) (Table 2).

c-MYC staining in native squamous oesophageal epithelium was confined to the nuclei of cells in the proliferative basal layer. No immunoreactivity was observed on sections of normal gastric fundus. Barrett's metaplasia exhibited weak to moderate nuclear staining; however, heterogeneity is suggested since staining was not evident in all glands within a single specimen. Dysplastic Barrett's glands demonstrated evidence of nuclear and cytoplasmic c-MYC expression. Immunoreactivity was widespread and intense in the majority of adenocarcinoma sections, indicating both nuclear and cytoplasmic expression in most cases (Figure 3). Semi-quantitative analysis suggested that c-MYC expression in dysplastic Barrett's mucosa and adenocarcinoma tissue was significantly higher than in normal oesophageal and gastric mucosae. Expression in Barrett's metaplasia was lower than in both dysplasia and adenocarcinoma but significantly higher than in normal stomach (Table 2).

Weak diffuse cytoplasmic MAD1 immunoreactivity was observed in normal oesophageal and gastric mucosae and Barrett's metaplasia. In squamous epithelium staining was localised to the suprabasal differentiated compartment of the epithelium, gastric mucosa also demonstrated evidence of nuclear immunoreactivity in some of the positively stained glands. Only $25 \%$ of Barrett's metaplasia displayed MAD1 immunoreactivity, similarly half of the examples of dysplastic Barrett's epithelium remained negative; immunoreactivity on the positive sections was indicative of increased cytoplasmic expression in both cases. Staining in adenocarcinoma was more evident, with sections demonstrating cytoplasmic staining with intensity ranging from weak to strong (Figure 3). Semi-quantitative analysis indicated that expression in adenocarcinoma was greater than normal oesophageal and gastric epithelia and non-dysplastic Barrett's metaplasia (Table 2).

The majority of normal oesophageal epithelium sections did not display any MXI1 immunoreactivity, in those that did staining was weak and localised to the nuclei and cytoplasm of the epibasal cells. In gastric fundus expression of MXI1 was limited, with a small amount of weak cytoplasmic staining in some sections; the nuclei of the adjacent lymphoid cells stained positively for MXI1. Immunoreactivity was evident in approximately one-third of Barrett's metaplasia specimens and demonstrated cytoplasmic expression of weak to moderate intensity. A pattern of expression also evident in dysplastic tissue with staining consistently moderate in intensity. MXI1 immunoreactivity in oesophageal adenocarcinomas was largely moderate in intensity and cytoplasmic in localisation (Figure 3). Epithelial immunoreactivity in tumours was significantly more intense and widespread than in normal oesophagus, stomach and benign and dysplastic Barrett's metaplasia (Table 2).

In normal oesophageal epithelium MAX immunoreactivity was moderately intense in the nuclei and weak in the cytoplasm of the suprabasal layers of the stratified epithelium. In normal fundal mucosa immunoreactivity was moderately intense and largely nuclear; Barrett's metaplasia however, displayed weak immuno- 


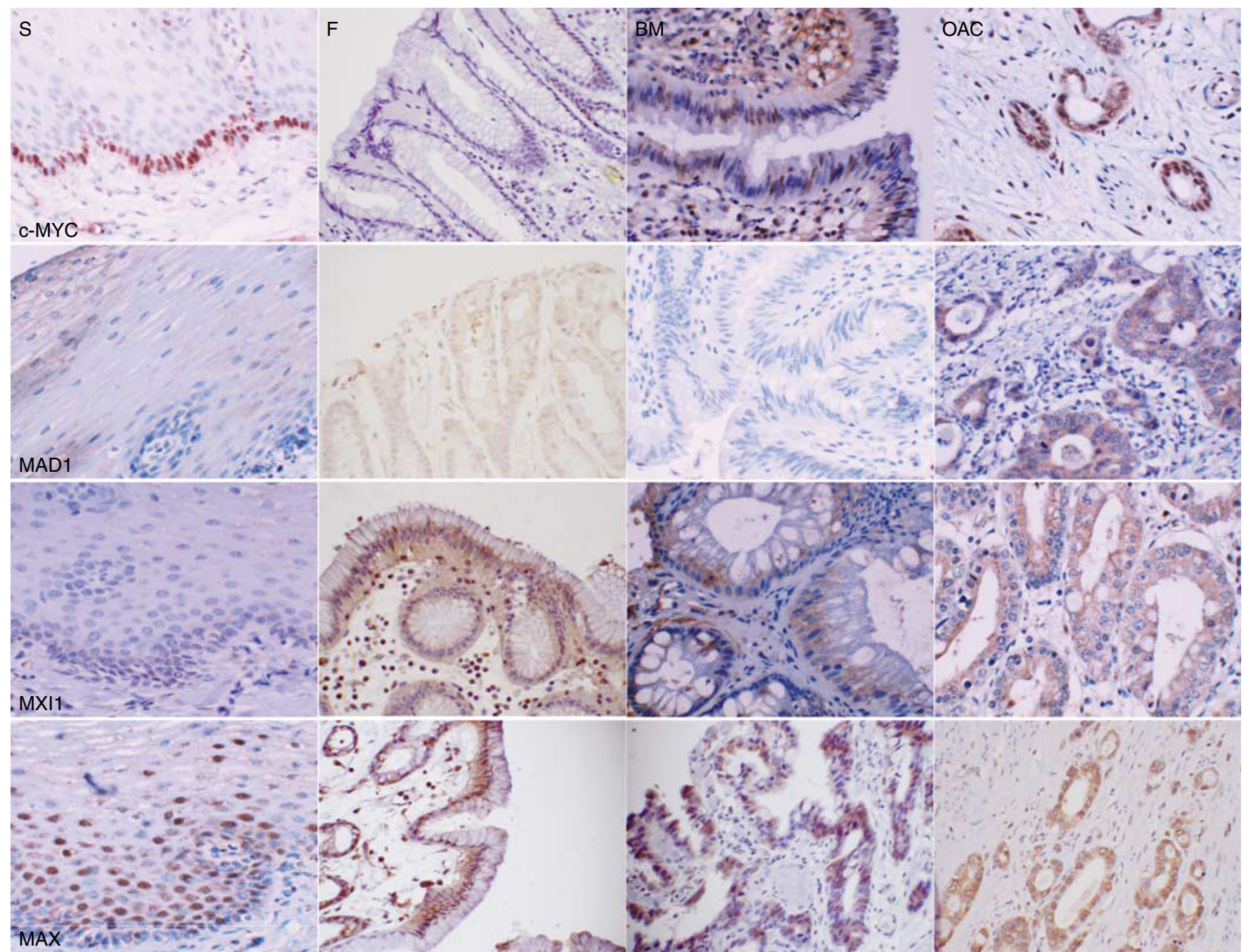

Figure 3 Immunolocalisation of MYC/MAX/MAD network proteins in Barrett's metaplasia and oesophageal adenocarcinoma. Paraffin sections of normal oesophagus, normal gastric fundus, Barrett's metaplasia and oesophageal adenocarcinoma were subjected to immunohistochemistry using antibodies designed against c-MYC, MADI, MXII and MAX. Magnification $\times 40$

Table 2 Semi-quantitative analysis of c-MYC network proteins in the oesophagus

\begin{tabular}{lcccccc}
\hline Protein & \multicolumn{5}{c}{ Mean score of immunoreactivity } \\
& S & F & BM & BD & OAC \\
\hline C-MYC & $1.50 \pm 0.2$ & $0.50 \pm 0.3$ & $\mathbf{2 . 4 2} \pm \mathbf{0 . 5}$ & $\mathbf{4 . 0 0} \pm \mathbf{0 . 7} * \ddagger$ & $\mathbf{7 . 7 0} \pm \mathbf{0 . 8} * \ddagger \circ$ \\
MADI & $1.00 \pm 0.4$ & $1.25 \pm 0.3$ & $0.54 \pm 0.3$ & $1.81 \pm 0.5$ & $\mathbf{3 . 9 7} \pm \mathbf{0 . 6} * \neq \circ$ \\
MXII & $0.50 \pm 0.3$ & $1.50 \pm 0.4$ & $0.78 \pm 0.2$ & $1.42 \pm 0.6$ & $\mathbf{4 . 0 6} \pm \mathbf{0 . 5} * \ddagger \circ$ \\
MAX & $4.33 \pm 1.3$ & $2.00 \pm 1.2$ & $1.90 \pm 0.3$ & $\mathbf{3 . 7} \pm \mathbf{0 . 7 7}$ & $\mathbf{8 . 0 0} \pm \mathbf{0 . 6 9} * \neq$
\end{tabular}

Immunohistochemistry for C-MYC, MADI, MXII and MAX was performed on paraffin sections of normal squamous oesophageal mucosa (S), normal gastric fundus (F), Barrett's metaplasia (BM), dysplastic Barrett's (BD) and oesophageal adenocarcinoma (OAC). Immunoreactivity was scored as described in Materials and methods. The mean score is displayed \pm I s.e.m. * denotes significant change in comparison to $\mathrm{S} ;{ }^{\ddagger}$ denotes statistical significance compared to $\mathrm{F} ;{ }^{\circ}$ denotes significance relative to $\mathrm{BM}$, $(P<0.05)$.

reactivity that was predominantly cytoplasmic. Staining in Barrett's dysplasia was also cytoplasmic but of moderate intensity. Adenocarcinoma sections displayed MAX immunoreactivity localised to both nuclei and cytoplasm (Figure 3). Semi-quantitative analysis suggested that MAX expression was significantly higher in adenocarcinoma than in normal mucosae and Barrett's metaplasia (Table 2).

\section{Overexpression of c-MYCER and MAD1 in SEG1 cells}

An oesophageal adenocarcinoma cell line, SEG1, was transiently transfected with pcDNA3.1-MYCER, pcDNA3-MAD1 or the corresponding empty vectors. To activate c-MYC 4-OHT was applied to the cells $24 \mathrm{~h}$ after transfection. Significant overexpression of c-MYC and MAD1 was demonstrated at mRNA and protein level by qRT - PCR and western blotting, respectively $48 \mathrm{~h}$ following transfection (Figure $4 \mathrm{~A}$ and $\mathrm{B}$ ).

The expression of other members of the MYC/MAX/MAD network was assessed in transfected cells. MYCER expressing cells demonstrated elevated levels of the mRNA encoding MXI1-0 $(P<0.001)$ (Figure 5A), whereas MAD1-overexpressing SEG1 cells demonstrated elevated $M Y C, M X I 1$ and repressed $M A X$ expression ( $P=0.002, P=0.014, P=0.03$, respectively) (Figure $5 \mathrm{~B})$. Activated SEG1-MYCER cells demonstrated significantly higher BrdU incorporation over $72 \mathrm{~h}$ than the untreated controls $(107 \pm 2 \%$, $P=0.024$ ), conversely SEG1-MAD1 proliferated at a significantly slower rate than mock transfected controls $(87 \pm 2 \%, P=0.006)$. These overexpression studies were similarly reproduced in other 


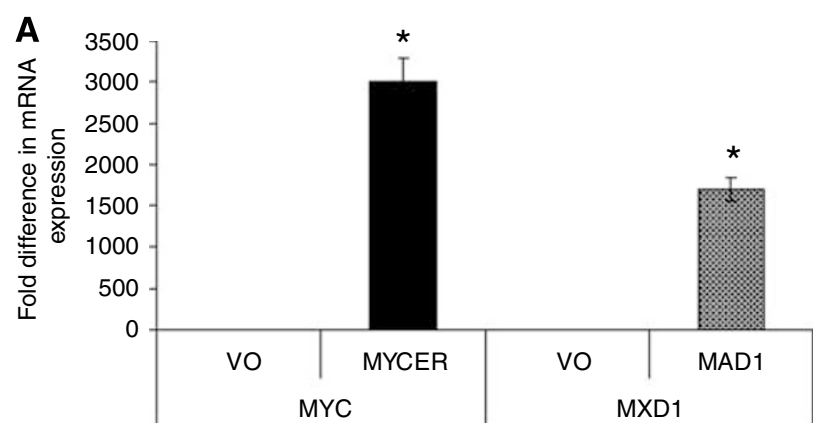

A

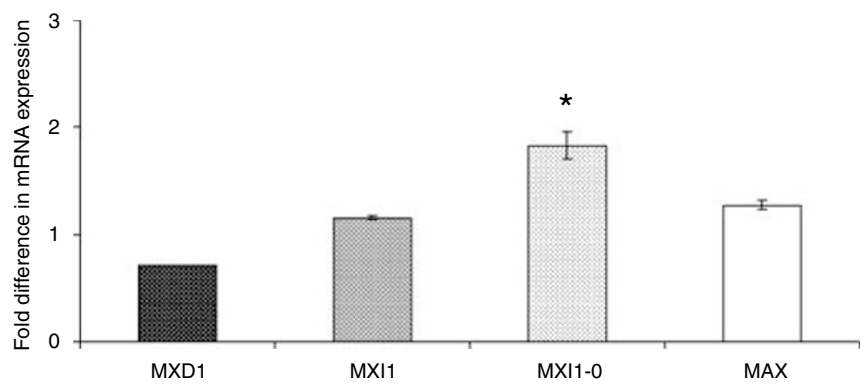

B

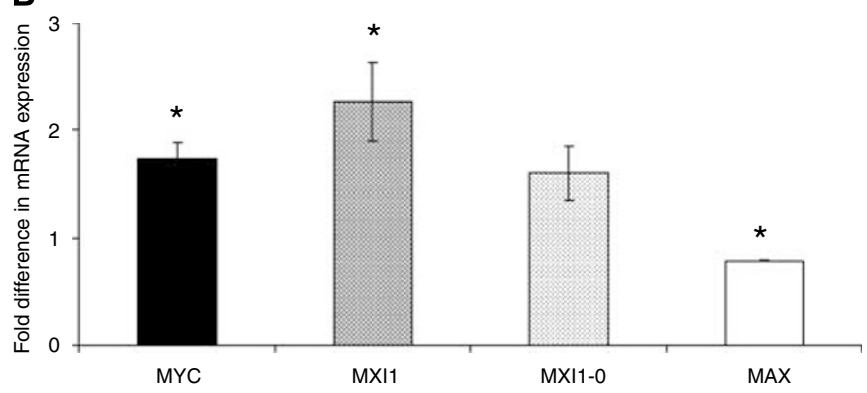

Figure 5 c-MYC network expression in SEGI cells expressing exogenous MYC/MAX/MAD network proteins. (A) qRT-PCR was utilised

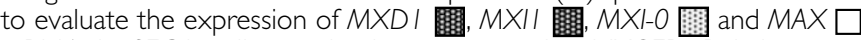
mRNA in SEGI cells transiently overexpressing MYCER. Relative gene expression is expressed as a ratio of SEGI-MYCER not stimulated using

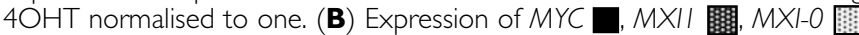
and MAX $\square$ mRNA was assessed in SEGI cells transiently overexpressing MADI. Relative gene expression is expressed as a ratio of mock transfected cells normalised to one. Data represent the mean of two independent experiments each performed in triplicate \pm I s.e.m. * denotes statistical significance $(P<0.05)$.

In light of the observations of reduced MAD1 expression in Barrett's metaplasia and previous evidence of $M X D 1$ repression in oesophageal adenocarcinoma (Hourihan et al, 2003), the trend towards upregulation of MAD1 in adenocarcinomas was not anticipated and would appear to be in conflict with the suggestion that MAD1 may have a role as a tumour suppressor (Ayer et al, 1993; Zervos et al, 1993; Cultraro et al, 1997; Queva et al, 1998). In support of the observations made here, MAD1 expression has been identified in benign and malignant murine skin tumours where the differentiation capacity was retained (Lymboussaki et al, 1996). Similarly, MAD1 expression has been identified in invasive ductal breast carcinomas of a well-differentiated phenotype (Han et al, 2000). It is possible therefore that an increase in MAD expression could be attributed to a negative feedback pathway to counteract aberrant MYC signalling and may be consistent with a role as a tumour suppressor. Indeed MXI1 upregulation has previously been observed downstream of MYC (Schuhmacher et al, 2001).

The overexpression of MXI1 in tumours may also, in part, be explained by the presence of differentially transcribed isoforms of MXI1 that lack important functional domains (Engstrom et al, 2004; Kawamata et al, 2005). MXI1-0 possesses an alternative first exon and as it does not express the same Sin3-interaction domain (SID), it is not capable of suppressing MYC-induced transformation. Overexpression of this isoform has been reported in glioblastomas in comparison with normal brain tissue (Engstrom et al, 2004) and therefore may represent the overexpressed isoform in oesophageal adenocarcinomas. Analysis of transcript levels by qRT-PCR allowed the expression of these isoforms to be differentiated; our data indicate that both isoforms are involved in the observed MXI1 overexpression in tumours, but that the 
putatively dominant negative isoform may be involved in the evolution of Barrett's metaplasia. Haematological tissue expresses three additional MXI1 isoforms, lacking either the SID-encoding first exon, the DNA-binding domain encoded by exon 3 or both these domains, which could also be considered in the oesophagus. Like MXI1-0, these isoforms may potentially exert a dominant negative effect (Kawamata et al, 2005).

MAX expression is widely acknowledged to be ubiquitous and in excess of other network members, whose expression is more tightly regulated (Blackwood and Eisenman, 1991; Berberich et al, 1992). Therefore, it was interesting to observe an increase in its expression in oesophageal adenocarcinoma. It has been suggested that although MAX is likely to be in excess of c-MYC and other binding partners in most circumstances, it may be limiting during the period when c-MYC levels are sharply elevated during cell cycle entry (Walker et al, 2005). This raises the possibility that MAX may also be limiting in tumours where c-MYC levels are very high. The observed overexpression demonstrated here may act to overcome this limitation, and may limit the antagonistic relationship between $\mathrm{c}-\mathrm{MYC}$ and the MAD proteins that are evidently coexpressed. Increased MAX expression has been linked to increased proliferation (Martel et al, 1995), but the mechanism by which MAX overexpression may occur in tumours is elusive.

Cytoplasmic expression of MYC/MAX/MAD network proteins may be an indication that, although overexpression occurs, these proteins may not be completely functional. It has been suggested that cytoplasmic localisation of c-MYC in colon cancer may be due to alterations in the $\mathrm{C}$ terminus of the protein, reducing the efficiency of nuclear targeting (Royds et al, 1992). While this may also be the case for other network members, evidence of murine mmip2-mediated cytoplasmic translocation of mad proteins (Yin et al, 1999) and cytoplasmic localisation of MXI-0 (Engstrom et al, 2004) lend other potential mechanisms to cytoplasmic expression.

Consistent with in vitro and transgenic models of $M Y C$ amplification (Pelengaris et al, 2002), an increase in cellular proliferation was demonstrated following c-MYCER activation in SEG1 cells. c-MYC overexpression resulted in an increase in the expression of MXI1-0 but had no effect on MXI1 suggesting alternative factors involved in their expression. Indeed Engstrom

\section{REFERENCES}

Ayer DE, Kretzner L, Eisenman RN (1993) Mad: a heterodimeric partner for Max that antagonizes Myc transcriptional activity. Cell 72: 211-222

Bartsch D, Peiffer SL, Kaleem Z, Wells Jr SA, Goodfellow PJ (1996) Mxi1 tumor suppressor gene is not mutated in primary pancreatic adenocarcinoma. Cancer Lett 102: 73-76

Benson LQ, Coon MR, Krueger LM, Han GC, Sarnaik AA, Wechsler DS (1999) Expression of MXI1, a Myc antagonist, is regulated by Sp1 and AP2. J Biol Chem 274: 28794-28802

Berberich S, Hyde-DeRuyscher N, Espenshade P, Cole M (1992) Max encodes a sequence-specific DNA-binding protein and is not regulated by serum growth factors. Oncogene 7: 775-779

Bernasconi NL, Wormhoudt TA, Laird-Offringa IA (2000) Post-transcriptional deregulation of myc genes in lung cancer cell lines. Am J Respir Cell Mol Biol 23: 560-565

Blackwood EM, Eisenman RN (1991) Max: a helix-loop-helix zipper protein that forms a sequence-specific DNA-binding complex with Myc. Science 251: $1211-1217$

Bollschweiler E, Wolfgarten E, Gutschow C, Holscher AH (2001) Demographic variations in the rising incidence of esophageal adenocarcinoma in white males. Cancer 92: 549-555

Brookes MJ, Hughes S, Turner FE, Reynolds G, Sharma N, Ismail T, Berx G, McKie AT, Hotchin N, Anderson GJ, Iqbal T, Tselepis C (2006) Modulation of iron transport proteins in human colorectal carcinogenesis. Gut 55: 1449-1460

Chen J, Willingham T, Margraf LR, Schreiber-Agus N, DePinho RA, Nisen PD (1995) Effects of the MYC oncogene antagonist, MAD, on et al (2004) suggest that regulation of MXI1-0 may differ from the AP2-mediated repression of the MXI1 promoter (Benson et al, 1999). As MXI1-0 is thought to lack the antagonistic effects of MXI1, one may suggest that increased expression may facilitate the activity of c-MYC.

MAD1 overexpression in SEG1 cells resulted in a reduction in cellular proliferation at $72 \mathrm{~h}$ in concordance with earlier studies associating MAD1 with reduced cell cycling and compromised tumourigenicity and colony formation (Chen et al, 1995; Wechsler et al, 1997). MAD1 overexpression has previously been associated with accumulation of cells in G0/G1 mediated in part by limited G1 phase cyclin/CDK complex kinase activity and moderate increases in the expression of CDK inhibitors $\mathrm{p} 27^{\mathrm{KIP} 1}$ and $\mathrm{p} 21^{\mathrm{CIP} 1}$. Although the observations made in SEG1 cells are consistent with previous overexpression studies, they oppose the observation that MAD1 is overexpressed in oesophageal adenocarcinoma.

To conclude, the overexpression of c-MYC in Barrett's metaplasia and oesophageal adenocarcinoma has been confirmed. Interestingly, this was accompanied by an overexpression of c-MYC antagonists MAD1 and MXI1 in many tumours. These observations demonstrate that the expression patterns and regulation of this network of proteins may be more complex than initially predicted. This may, in part, be due to the natural heterogeneity of tumour tissue, indeed localisation by immunohistochemistry demonstrated heterogeneous staining. Multiple isoforms of MXI1 have been identified in a variety of tissues, which raises the possibility that alternative isoforms of other network members might exist that interfere with their previously known functions. Therefore, it is worth considering that any MYCtargeted therapy approach may also need to take into account the action of the MAD family proteins.

\section{ACKNOWLEDGEMENTS}

This research was supported by a grant from University of Birmingham Medical School Studentship Committee

\section{Competing interests}

None declared. proliferation, cell cycling and the malignant phenotype of human brain tumour cells. Nat Med 1: 638-643

Chiariello M, Marinissen MJ, Gutkind JS (2001) Regulation of c-myc expression by PDGF through Rho GTPases. Nat Cell Biol 3: 580-586

Chin L, Schreiber-Agus N, Pellicer I, Chen K, Lee HW, Dudast M, CordonCardo C, DePinho RA (1995) Contrasting roles for Myc and Mad proteins in cellular growth and differentiation. Proc Natl Acad Sci USA 92: 8488-8492

Croft J, Parry EM, Jenkins GJ, Doak SH, Baxter JN, Griffiths AP, Brown TH, Parry JM (2002) Analysis of the premalignant stages of Barrett's oesophagus through to adenocarcinoma by comparative genomic hybridization. Eur J Gastroenterol Hepatol 14: 1179-1186

Cultraro CM, Bino T, Segal S (1997) Regulated expression and function of the c-Myc antagonist, Mad1, during a molecular switch from proliferation to differentiation. Curr Top Microbiol Immunol 224: 149-158

Dang CV (1999) c-Myc target genes involved in cell growth, apoptosis, and metabolism. Mol Cell Biol 19: 1-11

Di Martino E, Wild CP, Rotimi O, Darnton JS, Olliver RJ, Hardie LJ (2006) IGFBP-3 and IGFBP-10 (CYR61) up-regulation during the development of Barrett's oesophagus and associated oesophageal adenocarcinoma: potential biomarkers of disease risk. Biomarkers 11: 547-561

Doak SH, Jenkins GJ, Parry EM, D’Souza FR, Griffiths AP, Toffazal N, Shah V, Baxter JN, Parry JM (2003) Chromosome 4 hyperploidy represents an early genetic aberration in premalignant Barrett's oesophagus. Gut 52: $623-628$

Engstrom LD, Youkilis AS, Gorelick JL, Zheng D, Ackley V, Petroff CA, Benson LQ, Coon MR, Zhu X, Hanash SM, Wechsler DS (2004) Mxil-0, 
an alternatively transcribed Mxi1 isoform, is overexpressed in glioblastomas. Neoplasia 6: $660-673$

Grandori C, Cowley SM, James LP, Eisenman RN (2000) The Myc/Max/Mad network and the transcriptional control of cell behavior. Annu Rev Cell Dev Biol 16: 653-699

Gray IC, Phillips SM, Lee SJ, Neoptolemos JP, Weissenbach J, Spurr NK (1995) Loss of the chromosomal region 10q23-25 in prostate cancer. Cancer Res 55: 4800-4803

Hage M, Siersema PD, van Dekken H, Steyerberg EW, Dees J, Kuipers EJ (2004) Oesophageal cancer incidence and mortality in patients with longsegment Barrett's oesophagus after a mean follow-up of 12.7 years. Scand J Gastroenterol 39: 1175 - 1179

Han S, Park K, Kim HY, Lee MS, Kim HJ, Kim YD, Yuh YJ, Kim SR, Suh HS (2000) Clinical implication of altered expression of Mad1 protein in human breast carcinoma. Cancer 88: $1623-1632$

Hourihan RN, O'Sullivan GC, Morgan JG (2003) Transcriptional gene expression profiles of oesophageal adenocarcinoma and normal oesophageal tissues. Anticancer Res 23: $161-165$

Hughes SJ, Nambu Y, Soldes OS, Hamstra D, Rehemtulla A, Iannettoni MD, Orringer MB, Beer DG (1997) Fas/APO-1 (CD95) is not translocated to the cell membrane in esophageal adenocarcinoma. Cancer Res 57: $5571-5578$

Hurlin PJ, Foley KP, Ayer DE, Eisenman RN, Hanahan D, Arbeit JM (1995a) Regulation of Myc and Mad during epidermal differentiation and HPVassociated tumorigenesis. Oncogene 11: 2487-2501

Hurlin PJ, Queva C, Koskinen PJ, Steingrimsson E, Ayer DE, Copeland NG, Jenkins NA, Eisenman RN (1995b) Mad3 and Mad4: novel Maxinteracting transcriptional repressors that suppress c-myc dependent transformation and are expressed during neural and epidermal differentiation. EMBO J 14: 5646-5659

Jankowski JA, Harrison RF, Perry I, Balkwill F, Tselepis C (2000) Barrett's metaplasia. Lancet 356: $2079-2085$

Kawamata N, Sugimoto KJ, Sakajiri S, Oshimi K, Koeffler HP (2005) Mxi1 isoforms are expressed in hematological cell lines and normal bone marrow. Int J Oncol 26: 1369-1375

Kuczyk MA, Serth J, Bokemeyer C, Schwede J, Herrmann R, Machtens S, Grunewald V, Hofner K, Jonas U (1998) The MXI1 tumor suppressor gene is not mutated in primary prostate cancer. Oncol Rep 5: $213-216$

Lagergren J (2005) Adenocarcinoma of oesophagus: what exactly is the size of the problem and who is at risk? Gut 54(Suppl 1): i1 -i5

Larsson LG, Pettersson M, Oberg F, Nilsson K, Luscher B (1994) Expression of mad, mxil, max and c-myc during induced differentiation of hematopoietic cells: opposite regulation of mad and c-myc. Oncogene 9: $1247-1252$

Littlewood TD, Hancock DC, Danielian PS, Parker MG, Evan GI (1995) A modified oestrogen receptor ligand-binding domain as an improved switch for the regulation of heterologous proteins. Nucleic Acids Res 23: $1686-1690$

Lymboussaki A, Kaipainen A, Hatva E, Vastrik I, Jeskanen L, Jalkanen M, Werner S, Stenback F, Alitalo R (1996) Expression of Mad, an antagonist of Myc oncoprotein function, in differentiating keratinocytes during tumorigenesis of the skin. Br J Cancer 73: 1347-1355

Martel C, Lallemand D, Cremisi C (1995) Specific c-myc and max regulation in epithelial cells. Oncogene 10: 2195-2205

Nesbit CE, Tersak JM, Prochownik EV (1999) MYC oncogenes and human neoplastic disease. Oncogene 18: 3004-3016

Osterland CK, Wilkinson RD, St Louis EA (1990) Expression of c-myc protein in skin and synovium in psoriasis and psoriatic arthritis. Clin Exp Rheumatol 8: $145-150$
Pelengaris S, Khan M, Evan G (2002) c-MYC: more than just a matter of life and death. Nat Rev Cancer 2: 764-776

Pelengaris S, Littlewood T, Khan M, Elia G, Evan G (1999) Reversible activation of c-Myc in skin: induction of a complex neoplastic phenotype by a single oncogenic lesion. Mol Cell 3: 565-577

Pelengaris S, Rudolph B, Littlewood T (2000) Action of Myc in vivoproliferation and apoptosis. Curr Opin Genet Dev 10: 100-105

Queva C, Hurlin PJ, Foley KP, Eisenman RN (1998) Sequential expression of the MAD family of transcriptional repressors during differentiation and development. Oncogene 16: $967-977$

Royds JA, Sharrard RM, Wagner B, Polacarz SV (1992) Cellular localisation of c-myc product in human colorectal epithelial neoplasia. J Pathol 166: $225-233$

Salghetti SE, Kim SY, Tansey WP (1999) Destruction of Myc by ubiquitinmediated proteolysis: cancer-associated and transforming mutations stabilize Myc. EMBO J 18: 717-726

Sant M, Aareleid T, Berrino F, Bielska Lasota M, Carli PM, Faivre J, Grosclaude P, Hedelin G, Matsuda T, Moller H, Moller T, Verdecchia A, Capocaccia R, Gatta G, Micheli A, Santaquilani M, Roazzi P, Lisi D, the EUROCARE Working Group (2003) EUROCARE-3: survival of cancer patients diagnosed 1990-94-results and commentary. Ann Oncol 14: v61 - v118

Schmidt MK, Meurer L, Volkweis BS, Edelweiss MI, Schirmer CC, Kruel CDP, Gurski RR (2007) c-Myc overexpression is strongly associated with metaplasia-dysplasia-adenocarcinoma sequence in the esophagus. Diseases Esophagus 20: 212-216

Schuhmacher M, Kohlhuber F, Holzel M, Kaiser C, Burtscher H, Jarsch M, Bornkamm GW, Laux G, Polack A, Weidle UH, Eick D (2001) The transcriptional program of a human B cell line in response to Myc. $\mathrm{Nucl}$ Acids Res 29: 397 - 406

Solaymani-Dodaran M, Logan RF, West J, Card T, Coupland C (2004) Risk of oesophageal cancer in Barrett's oesophagus and gastro-oesophageal reflux. Gut 53: $1070-1074$

Tselepis C, Morris CD, Wakelin D, Hardy R, Perry I, Luong QT, Harper E, Harrison R, Attwood SEA, Jankowski JAZ (2003) Upregulation of the oncogene c-myc in Barrett's adenocarcinoma: induction of c-myc by acidified bile acid in vitro. Gut 52: 174-180

van Dekken H, Vissers K, Tilanus HW, Kuo WL, Tanke HJ, Rosenberg C, Ijszenga M, Szuhai K (2006) Genomic array and expression analysis of frequent high-level amplifications in adenocarcinomas of the gastroesophageal junction. Cancer Genet Cytogenet 166: 157-162

Vastrik I, Kaipainen A, Penttila TL, Lymboussakis A, Alitalo R, Parvinen M, Alitalo K (1995) Expression of the mad gene during cell differentiation in vivo and its inhibition of cell growth in vitro. J Cell Biol 128: $1197-1208$

Walch AK, Zitzelsberger HF, Bruch J, Keller G, Angermeier D, Aubele MM, Mueller J, Stein H, Braselmann H, Siewert JR, Hofler H, Werner M (2000) Chromosomal imbalances in Barrett's adenocarcinoma and the metaplasia-dysplasia-carcinoma sequence. Am J Pathol 156: 555-566

Walker W, Zhou ZQ, Ota S, Wynshaw-Boris A, Hurlin PJ (2005) Mnt-Max to Myc-Max complex switching regulates cell cycle entry. J Cell Biol 169: $405-413$

Wechsler DS, Shelly CA, Petroff CA, Dang CV (1997) MXI1, a putative tumor suppressor gene, suppresses growth of human glioblastoma cells. Cancer Res 57: 4905-4912

Yin XY, Gupta K, Han WP, Levitan ES, Prochownik EV (1999) Mmip-2, a novel RING finger protein that interacts with mad members of the Myc oncoprotein network. Oncogene 18: 6621-6634

Zervos AS, Gyuris J, Brent R (1993) Mxi1, a protein that specifically interacts with Max to bind Myc-Max recognition sites. Cell 72: $223-232$ 